\title{
The effect of supplemental animal fat on yolk sac resorption, its chemical composition, and on pancreatic and serum enzyme activity in chickens
}

\author{
T. Wertelecki', D. Jamroz ${ }^{1}$ and K. A. Sobiech ${ }^{2}$ \\ 'Department of Animal Nutrition and Feed Quality, Wroclaw Agricultural University \\ Chelmonskiego 38D,51-630 Wroclaw, Poland \\ ${ }^{2}$ Department of Biochemical Science, Wroclaw Academy of Sport Science \\ Paderewskiego 5, 51-612 Wroclaw, Poland
}

(Received 4 May 2000; revised version 16 November 2000; accepted 20 April 2001)

\begin{abstract}
The study was conducted on 476 male Shaver Starbro chickens, divided into four groups and fed ad libinum diets differing in their lard content: $0,3,6$, or $9 \%$. On days $1,2,3,4,7,12$, and 21 days of life the chickens were weighed, some were killed, the yolk sac was weighed, and its crude protein and fat contents were determined. Amylase and lipase activity was assayed in the blood and pancreas.

The chickens fed fat-supplemented rations were heavier on day 21 of life. No significant differences were found, however, between groups in the decrease in yolk sac weight. A high fat content of the diet $(9 \%)$ slowed down the rate at which fat was resorbed from the yolk sac, but the chickens developed normally. Resorption of protein from the yolk sac by chickens given the unsupplemented feed was uniform. At a higher lard content in the dict, a tendency appeared towards reducing the rate of lipid resorption from the yolk sac; this process intensified after day 4 of life. The addition of lard to the dict significantly lowered the activity of lipase in the pancreas on 3 day of life and its gradual increase was observed between days 7 and 21 . The addition of fat to the diets at levels from 6 to $9 \%$ decreased the activity of pancreatic amylase on days 3 and 7 of life.
\end{abstract}

KEY WORDS: chickens, yoik sac, pancreas, blood, enzymes, fat

\section{INTRODUCTION}

The nutrients necessary for a chicken's development are stored in the egg and cannot be supplemented from outside. The nutrients of an egg should ensure the 
proper development of the embryo, and then of the chick that is capable of independent life (Nir et al., 1993). During the first 3-5 days of life, the basic source of energy for the chicken is the fat accumulated in the yolk sac. During incubation yolk sac is drawn into the body cavity; during the first $24 \mathrm{~h}$ of a chicken's life, the nutrients in the sac support its needs whether or not the chicken has access to feed and water (Escribano et al., 1988; Chamblee et al., 1992; Martin et al., 1992; Turro-Vincent et al., 1994; Jin et al., 1998). When a chicken hatches, the yolk sac accounts for $20-25 \%$ of its body weight; in the case of turkeys, $10-12 \%$ (Noy and Sklan, 1997). During the first hours of life, up to $20 \%$ of the yolk sac (by weight) is absorbed. After 36-48 h, the rate at which resorption occurs depends on the type and composition of the feed that the chicken receives, its energy value, as well as on the timing of the first feeding (Pisarski et al., 1998a,b; Wertelecki and Jamroz 1998,1999). If the diet given to chickens in the first days of life is too high in nutrients, it can disrupt the resorption of the yolk sac. This is important because the yolk sac supplies from 22 to $30 \%$ of the energy taken up in the first three days of life. Surgical removal of the yolk sac delays the growth rate of chickens by about two days; in meat breeds, removal inhibits normal growth to such an extent that it is very difficult to compensate for it by intensive feeding later (Murakami et al., 1988; Turro-Vincent et al., 1994a,b; Nitsan et al., 1995).

Much controversy surrounds the use of high-fat diets (with a large amount of added fat) from the very first day of life, when chickens are resorbing the contents of the yolk sac and the activity of the enzymes of gastrointestinal tract is low. Overburdening a poorly developed, immature gastrointestinal tract with a large amount of fat may lead to digestive disorders, even to diarrhoea.

The objective of this study was to examine the rate of resorption of yolk sac contents and changes in the activity of selected enzymes, using lard as the supplemental source of energy in diets of chickens.

\section{MATERIAL AND METHODS}

The experiment was conducted on 476 male Shaver Starbro broilers. The birds were taken from the hatchery $3-4 \mathrm{~h}$ from the time the hatching compartment were opened, transferred to the coop and randomly assigned to three-story cages, 17 birds per cage. Transportation of the chickens took about $40 \mathrm{~min}$. Three birds from each cage were randomly selected for analysis, which was done in the first day of life. Four experimental groups were formed, each with 7 replicates. The starter diets (Table 1) were isonitrogenous $(21.1 \%)$ and differed in the amount of added lard $(0,3,6$, or $9 \%)$ and energy value $(11.0-13.0 \mathrm{MJ} / \mathrm{kg})$. The chickens were fed $\mathrm{ad}$ libitum; feed intake was recorded. 
TABLE 1

Chemical composition of experimental diets', $\mathrm{g} \mathrm{kg}^{-1}$

\begin{tabular}{lrrrr}
\hline Ingredients & I & II & III & IV \\
\hline Maize & 300 & 350 & 400 & 350 \\
Wheat & 290 & 200 & 110 & 120 \\
Soyabean oilmeal & 370 & 380 & 390 & 400 \\
Lard & 0 & 30 & 60 & 90
\end{tabular}

Calculated

crude protein

212

212

212

212

metabolizable energy, $\mathrm{MJ} / \mathrm{kg}$

110

117

124

130

crude fat

23

53

112

${ }^{1}$ mineral-vitamin supplement for all diets $\left(\mathrm{g} \mathrm{kg}^{-1}\right)$ : limestone, 15 ; dicalcium phosphate, $12 ; \mathrm{NaCl}, 3$; mineral-vitamin premix ${ }^{2}, \mathrm{I} 0$

2 vitamin-mineral premix provided per kg diet: vit. A $12000 \mathrm{IU}$, vit. $\mathrm{D}_{3} 3000 \mathrm{IU}, \mathrm{mg}$ : vit. E 35; thiamin 3 ; riboflavin 7 ; pyridoxine 5 ; vit. $\mathrm{B}_{12} 0.02$; biotin 0.15 ; folic acid 15 ; niacin 40 ; panthotenic acid 14; Se 0.2; Co 0.3; Mg 20 and methionine; coccidiostat; growth promotor

Birds were sacrificed at 2, 3, 4, 7, 12, and 21 days of life, always $2 \mathrm{~h}$ after removing the feed. The randomly chosen chickens, 21 on day 1 and 14 from each group thereafter, were individually weighed, then stunned and decapitated. Blood was taken for analysis, the body cavity opened and the yolk sac removed, weighed and lyophilized using an Edwards apparatus. In the lyophilized material total nitrogen was determined in a Kjeltec 2300 Foss Tecator apparatus, and the crude protein $(\mathrm{N} \times 6.25)$ content was calculated, crude fat was assayed by the Soxhlet method. The whole pancreas was separated from the duodenal loop, weighed, immediately cooled in liquid nitrogen fumes to halt metabolic processes, then frozen in liquid nitrogen. Frozen pancreas was cut into small pieces, homogenized and centrifuged at $10000 \mathrm{rpm}$. In the supernatant protein content was determined and the activity of $\alpha$-amylase and lipase were assayed. Amylase activity was determined using the Enzyline $\alpha$-amylase RTU test no. $63 / 115 / 116 / 117$, lipase, Enzyline Lipase Color, test no. 63/108/109 from BioMerieux SA. The specific activity of the enzymes was expressed as the amount of product per unit of time per milligram of total protein of the pancreas. Protein was determined by the method of Lowry (Handbook of Biochemical Instructions, 1989).

The obtained results were subjected to statistical analysis using analysis of variance and Duncan's multiple rank test. The rate of resorption of protein and fat from yolk sacs is presented in the form of regression equations after logarithmic transformation of the data. 


\section{RESULTS}

In the second day of life, the body weight of the chickens in group III was the best in comparison with the other groups; this difference was significant in relation to group II $(\mathrm{P}<0.05$; Table 2$)$. The differences between groups were also significant $(\mathrm{P}<0.01)$ on days 12 and 21 . The chickens in groups III and IV were found to grow fastest.

TABLE 2

Body weight, $g$, and proportion of chickens with fully resorbed yolk sac, $\%$

\begin{tabular}{|c|c|c|c|c|c|}
\hline \multirow{2}{*}{$\begin{array}{l}\text { Day } \\
\text { of life }\end{array}$} & \multicolumn{5}{|c|}{ Groups - lard supplement, \% } \\
\hline & $1-0$ & II -3 & III -6 & IV -9 & SEM $^{\prime}$ \\
\hline \multicolumn{6}{|c|}{ Body weight, g } \\
\hline 1 & 39 & 41 & 41 & 39 & 3.3 \\
\hline 2 & $45^{\mathrm{ab}}$ & $45^{\mathrm{a}}$ & $49^{\mathrm{b}}$ & $47^{\mathrm{ab}}$ & 4.4 \\
\hline 3 & 52 & 51 & 55 & 55 & 6.5 \\
\hline 4 & 66 & 63 & 66 & 64 & 6.3 \\
\hline 7 & 109 & 111 & 112 & 106 & 13.2 \\
\hline 12 & $165^{\mathrm{a}}$ & $182^{\mathrm{ab}}$ & $188^{\mathrm{b}}$ & $172^{\mathrm{ab}}$ & 23.6 \\
\hline 21 & $562^{A s}$ & $606^{\text {ABab }}$ & $656^{\mathrm{Bc}}$ & $619^{\wedge \mathrm{Bhk}}$ & 61.3 \\
\hline \multicolumn{6}{|c|}{$\%$ of chickens with fully resorbed yolk sac } \\
\hline 7 & 57.2 & 64.3 & 42.8 & 35.7 & \\
\hline 12 & 28.6 & 85.8 & 64.3 & 57.2 & \\
\hline 21 & 85.7 & 100 & 78.5 & 85.7 & \\
\hline
\end{tabular}

abc $\mathrm{P}<0.05 ;{ }^{\mathrm{AB}} \mathrm{P}<0.01$

Feed consumption, determined for subgroups, depended on the metabolizable energy content of the feed. From day 7 to 12 of life, feed consumption was highest in group I, $21 \mathrm{~g}$ day $^{-1}$, and lowest in group III, $19 \mathrm{~g} \mathrm{day}^{-1}$. From day 12 to 21 , feed intake was the lowest in group IV, $45 \mathrm{~g} \mathrm{day}^{-1}$, and the highest in groups I and II, about $51 \mathrm{~g} \mathrm{day}^{-1}$ on average.

Resorption of yolk sacs, expressed as the decline in their weight, proceeded gradually from day 1 to 12 of life, but the differences among groups did not achieve significance. The values obtained on day 21 refer to single observations, increase in the size was the result of histological changes, encapsulation, and fibrosis of unresorbed yolk sacs (Table 3).

The crude protein content of the yolk sacs expressed as a percent of fresh weight already differed among groups on day $1(\mathrm{P}<0.05$; Figure 1$)$. The resorption rate of crude protein from the sacs was most uniform in group I; the addition of fat to the diet differentiated the groups. The lowest protein content of the yolk sacs was 
Weight of yolk sac, g, and its proportion in metabolic body weight $\mathrm{MC}^{0,67}, \%$

\begin{tabular}{ccccccccccc}
\hline \multirow{2}{*}{$\begin{array}{c}\text { Day } \\
\text { of life }\end{array}$} & \multicolumn{8}{c}{ Groups - lard supplenent, \% } \\
\cline { 2 - 11 } & II-0 & I1-3 & III-6 & IV-9 & SEM & I-0 & II-3 & III-6 & IV-9 & SEM \\
\hline 1 & 3.41 & 3.60 & 3.81 & 3.45 & 1.50 & 28.5 & 29.8 & 31.4 & 29.4 & 11.6 \\
2 & 2.33 & 2.50 & 1.95 & 2.83 & 1.09 & $18.0^{\text {ab }}$ & $19.5^{\text {ab }}$ & $14.1^{\text {a }}$ & $21.4^{\text {b }}$ & 8.1 \\
3 & 1.28 & 1.59 & 1.05 & 1.62 & 0.93 & 9.1 & 11.4 & 7.1 & 10.9 & 6.5 \\
4 & 1.08 & 1.09 & 0.93 & 0.75 & 0.78 & 6.6 & 7.0 & 5.7 & 4.6 & 4.9 \\
7 & 0.28 & 0.86 & 0.60 & 0.71 & 0.39 & 1.2 & 3.5 & 2.6 & 3.2 & 1.7 \\
12 & 0.69 & 0.26 & 0.55 & 0.66 & 0.56 & 2.4 & 0.8 & 1.6 & 2.2 & 1.8 \\
21 & 2.18 & - & 1.26 & 7.40 & 4.38 & 3.2 & - & 1.6 & 11.4 & 6.7 \\
\hline
\end{tabular}

as as in Table 2

found on day 7 in group IV. The fat content in the yolk sac, expressed as a percentage of fresh weight, was already highly differentiated on day 1 of life. The highest degree of fat resorption was found in groups I, and in II and III on day 2 of life. A high level of added fat $(9 \%)$ inhibited the absorption of endogenous lipids on days 2 and 3 of life and intensified this process starting from day 4 (Figure 2). The protein resorption rate expressed as averages computed by logarithmic transformation $\left(\log _{10}\right.$ ), was steady and similar in all groups (Figure 1 ). The rate of absorption of endogenous lipids depended on the fat content of the ration. The steepest slope was founded in group IV $(9 \%)$, the most gentle one was in group I $(0 \%)$ (Figure 2).

Table 2 shows the percentage of chickens with fully resorbed yolk sacs among the examined birds in the group. No remnants of yolk sacs were found on day 12 of life in $86 \%$, and on day 21 of life in any of the examined birds in group II. Birds from the other groups still had fibrotic remnants of yolk sacs on day 21 of life; these remnants were very enlarged in some.

The activity of $\alpha$-amylase in the blood of chickens on day 1 of life differed significantly among groups $(\mathrm{P}<0.05$; Table 4$)$. On day 3 , the highest activity of this enzyme was found in chickens in groups III and I, in older chickens, amylase activity was similar. The serum lipase activity on day 3 decreased, rose on day 7 and again declined on day 21 . The differences between groups were significant $(\mathrm{P}<0.05)$ only on day 3 of life. In seven-day-old chickens fed the diet without added fat, the activity of this enzyme in the serum was higher in comparison with the group that received diets containing added fat.

The amylolytic activity of the pancreas of one-day-old chickens differed significantly among groups $(\mathrm{P}<0.05$; Table 5$)$. On day 7 of life the activity of amylase was significantly higher in chickens fed diets without added fat than in the groups of chickens fed fat-supplemented diets $(\mathrm{P}<0.05)$. The value of the analyzed para- 


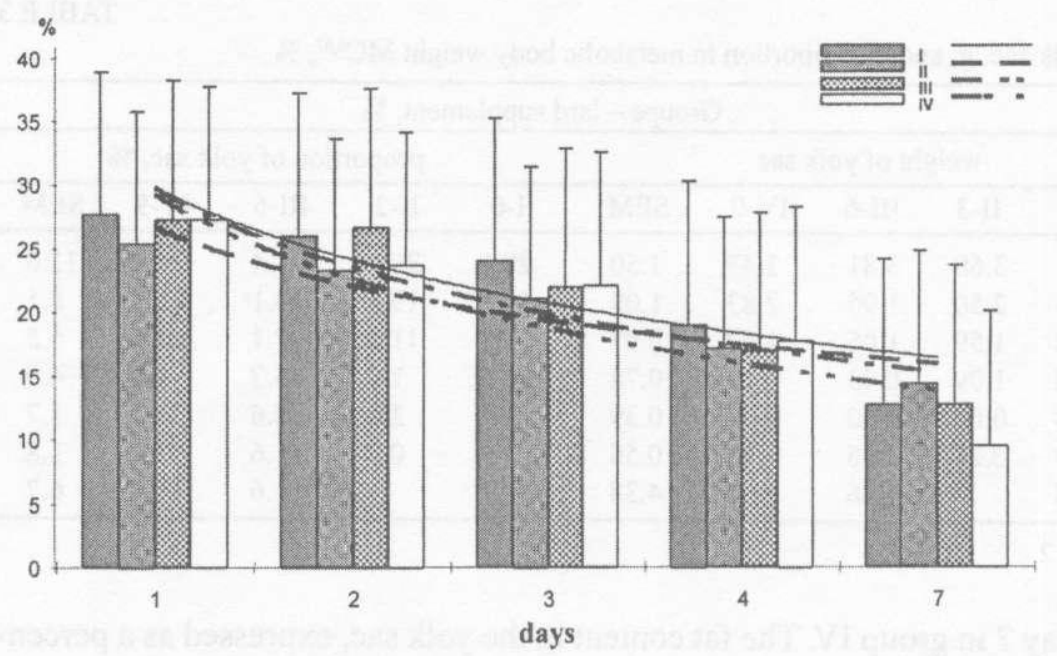

$\begin{array}{cccc}y \mid=-8,368 \operatorname{Ln}(x)+29.911 & y \|=-656 \operatorname{Ln}(x)+26.654 & y I I I=-9.00 \operatorname{Ln}(x)+29.791 & y I V=-9.560 \operatorname{Ln}(x)+29.232 \\ R^{2}=0.775 P<0.05 & R^{2}=0.896 P<0.05 & R^{2}=0.832 P<0.05 \quad R^{2}=0.796 P<0.05\end{array}$

Figure 1. Crude protein content in yolk sac, \%

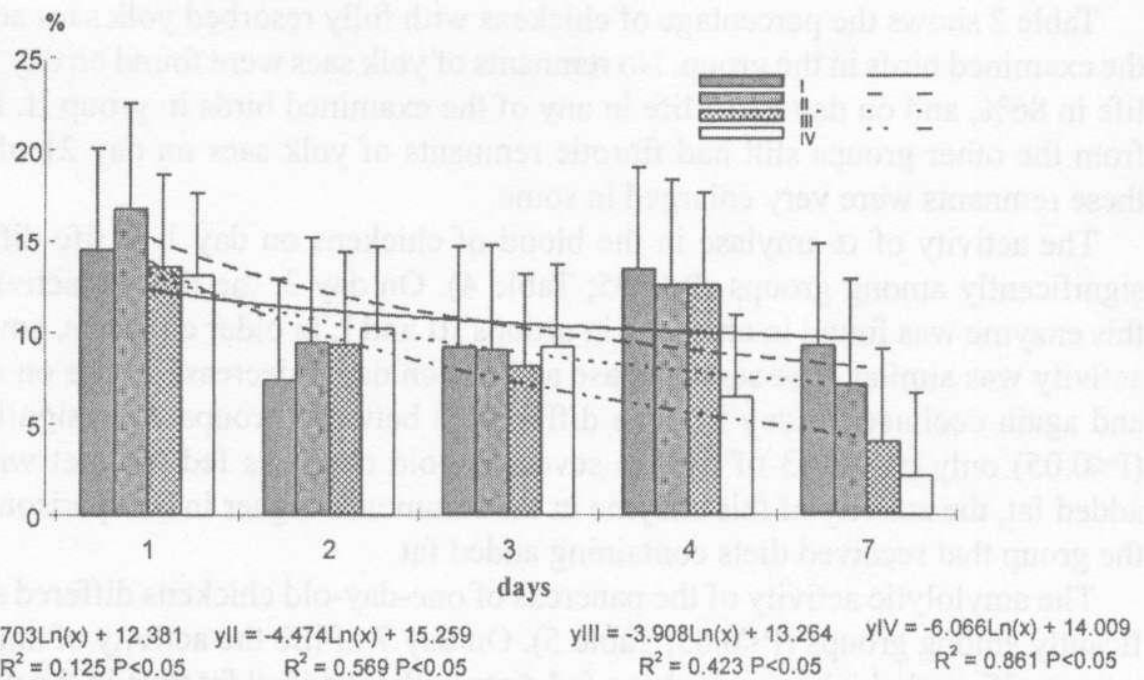

Figure 2. Crude fat content in yolk sac, \% 
meter on day 21 differed significantly $(\mathrm{P}<0.05)$. The addition of lard to feeds lowered the activity of pancreatic lipase on day 3 of life; it was highest in group I, lower in groups II and III $(\mathrm{P}<0.05)$. On day 21 of life a higher, albeit not significantly, activity of lipase was found in group IV. The observed tendency was proportional to the share of lard in the diet.

The weight of the pancreas in relation to metabolic body weight differed significantly among groups only on days 2 and 3 of life, and was highest in groups II and III $(\mathrm{P}<0.05)$. In somewhat older chickens, the addition of fat had no effect on the weight of the pancreas (Table 6).

\section{DISUSSION}

One of the important anatomical traits of healthy chickens is a properly resorbed yolk sac. Disorders of this process can lead to inflammation of the gastrointestinal tract. According to Noy and Sklan (1997) and Jin et al. (1998), when a chicken hatches, the yolk sac accounts for about $20-25 \%$ of its body weight. This

TABLE 4

$\alpha$-amylase and lipase activity in blood serum, $\mathrm{U} \mathrm{ml}^{-1}$

\begin{tabular}{|c|c|c|c|c|c|c|c|c|c|c|}
\hline \multirow{3}{*}{$\begin{array}{l}\text { Day } \\
\text { of life }\end{array}$} & \multicolumn{10}{|c|}{ Groups - lard supplement, \% } \\
\hline & \multicolumn{5}{|c|}{$\alpha$-amylase } & \multicolumn{5}{|c|}{ lipase } \\
\hline & $\mathrm{I}-0$ & II -3 & III-6 & IV -9 & SEM & $1-0$ & II -3 & III-6 & IV -9 & SEM \\
\hline 1 & $1414^{\mathrm{a}}$ & $1401^{\circ}$ & $1374^{\mathrm{a}}$ & $1664^{b}$ & 170 & $18.7^{\text {ah }}$ & $23.2^{\mathrm{b}}$ & $16.6^{\mathrm{ab}}$ & $14.2^{a}$ & 4.5 \\
\hline 3 & 1952 & 1382 & 2553 & 1382 & 650 & $9.5^{\mathrm{b}}$ & $3.9^{\mathrm{a}}$ & $3.2^{a}$ & $3.4^{a}$ & 1.93 \\
\hline 7 & 1719 & 1734 & 2015 & 2677 & 640 & 40.3 & 25.5 & 30.6 & 32.7 & 11.1 \\
\hline 21 & 1113 & 964 & 1184 & 1098 & 290 & 17.6 & 13.6 & 18.1 & 18.3 & 3.5 \\
\hline
\end{tabular}

ab as in Table 2

TABLE 5

$\alpha$-amylase and lipase activity in pancreas, $\mathrm{U} \mathrm{mg}^{-1}$ total protein

\begin{tabular}{|c|c|c|c|c|c|c|c|c|c|c|}
\hline \multirow{3}{*}{$\begin{array}{l}\text { Day } \\
\text { of life }\end{array}$} & \multicolumn{10}{|c|}{ Groups - lard supplement, $\%$} \\
\hline & \multicolumn{5}{|c|}{$\alpha$-amylase } & \multicolumn{5}{|c|}{ lipase } \\
\hline & $\mathrm{I}-0$ & II-3 & III-6 & IV -9 & SEM & $\mathrm{I}-0$ & II-3 & III-6 & IV-9 & SEM \\
\hline 1 & $2.88^{a}$ & $4.44^{i b}$ & $4.02^{\mathrm{ab}}$ & $9.10^{\mathrm{b}}$ & 2.6 & 1.28 & 1.15 & 1.24 & 1.29 & 0.4 \\
\hline 3 & 27.36 & 23.09 & 22.68 & 22.25 & 4.4 & $1.46^{\mathrm{b}}$ & $1.06^{\mathrm{ab}}$ & $1.03^{\mathrm{a}}$ & $1.19^{\mathrm{ab}}$ & 0.3 \\
\hline 7 & $42.28^{\mathrm{b}}$ & $10.33^{\mathrm{a}}$ & $4.88^{\mathrm{a}}$ & $5.57^{\mathrm{a}}$ & 5.3 & 1.57 & 0.97 & 1.63 & 1.38 & 0.5 \\
\hline 21 & $53.84^{\mathrm{b}}$ & $41.16^{\mathrm{a}}$ & $54.94^{b}$ & $49.53^{a b}$ & 8.3 & 2.43 & 2.61 & 2.68 & 3.85 & 1.1 \\
\hline
\end{tabular}

${ }^{\mathrm{ab}}$ as in Table 2 
TABELA 6

Weight of pancreas $\mathrm{mg} \mathrm{g}^{-1} \mathrm{MC}^{0.67}$

\begin{tabular}{lccccc}
\hline \multirow{2}{*}{$\begin{array}{l}\text { Day } \\
\text { of life }\end{array}$} & \multicolumn{5}{c}{ Groups } \\
\cline { 2 - 6 } & II-0 & II-3 & III-6 & IV-9 & SEM \\
\cline { 2 - 6 } & 760 & 820 & 770 & 830 & 215 \\
\hline 1 & $1030^{\mathrm{a}}$ & $1060^{\mathrm{a}}$ & $1260^{\mathrm{b}}$ & $1070^{\mathrm{a}}$ & 240 \\
2 & $1460^{\mathrm{a}}$ & $1500^{\mathrm{a}}$ & $1820^{\mathrm{b}}$ & $1460^{\mathrm{a}}$ & 340 \\
3 & 1910 & 2020 & 1940 & 1870 & 385 \\
4 & 2680 & 3000 & 2940 & 2800 & 597 \\
7 & 3230 & 3070 & 3140 & 3220 & 755 \\
12 & 3460 & 3330 & 3355 & 3320 & 372 \\
21 & & & & & \\
\hline
\end{tabular}

${ }^{a b}$ as in Table 2

is in line with our own observations, in which the weight of the yolk sac in chickens expressed in relation to metabolic body weight (MBW) was $28-31 \%$ in the first day of life. The proportion of the sac in MBW declined as the chickens grew, and the weight of the sac itself gradually decreased. This was not a linear process and its greatest intensity was observed between days 2 and 4 of life. High variability was observed among the chickens in terms of the analyzed parameters. According to various authors, resorption of the sac should be completed by day 5 of life, leaving only the Meckel's diverticulum on the small intestine (Kuenzel and Kuenzel, 1977; Sell et al., 1991; Noy and Sklan, 1995; Noy et al., 1996). As Wertelecki and Jamroz $(1998,1999)$ have shown in their studies, remnants of yolk sacs have been found in normally developing chickens even on day 21 of life; the average weight of these structures was from 0.08 to even $7.4 \mathrm{~g}$. It is difficult, however, to conclude on this basis if such a course of resorption had a negative impact on the future development of the chickens or not because these observations were made only in chickens that had been slaughtered. A high-level of fat (lard) in the diet $(9 \%)$ was not conducive to rapid resorption of the yolk sac.

The dynamic of fat resorption (Figure 2) indicates that as the amount of lard added to the diet increased, particularly at the level of $9 \%$, the rate of absorption of endogenous lipids decreased over level of days 2 and 3, after which it gradually rose. From day 4 of life, a distinct loss of fat from the sacs was noted. It can thus be agreed with other authors that when the apparent digestibility of exogenous fat declines, around day 7 of life, the absorption of endogenous fat can increase again, as seen on days 7 and 12. Carew et al. (1972) reported similar observations. It also seems important that adding fat to the diets of young chickens up to day 5 of life does not give uniform results (Jamroz and Wertelecki, 1998a). The studies of Chamblee et al. (1992) support this conclusion. In these studies, fat was added to the diet in order to compensate the impact of excision of the yolk sac on growth. No dis- 
tinct effects were observed until after day 15 of life, i.e. not before the metabolism of exogenous lipids was fully developed. The lipid fraction in diets for young chickens should therefore be balanced in a way allowing the chicken to make maximum use of endogenous lipids during the period when it has the peak physiological ability to metabolize them. The fat level and energy density of the feed should be concomitantly increased but only when the enzymatic and digestive system of the chicken is better developed, i.e. after day 7 of life.

Changes in the amount of crude protein in yolk sacs of chickens were only slightly dependent on the amount of fat added to the diet. On day 1 of life the amount of crude protein in the sacs averaged $26-29 \%$; in the studies of Hemin et al. (1994), 19\%. In our experiment, on day 3 of life the amount of protein ranged from 19 to $25 \%$. The absorption rate of endogenous protein during the first days of life was low and gradually increased, but with a slower dynamic than fat. During the first days of a chicken's life, proteolytic processes are not fully developed (Sklan and Hurwitz, 1980; Katanabaf et al., 1988; Susbilla et al., 1994). The pancreas of chickens achieves optimal proteolytic activity at the age of 21-28 days (Krogdahl et al., 1989). Noy and Sklan (1995) and Uni et al. (1995) found that protein digestibility on day 4 was $78 \%$, rising to about $90 \%$ from day 14 of life. The slower rate of absorbing endogenous protein found in our study was in line with the results of Krogdahl et al. (1989), Noy and Sklan (1995), Uni et al. (1995), and others.

Resorption of yolk sacs up to 7 day of life by chickens fed diets with higher fat levels was somewhat less efficient. Interestingly, the addition of animal fat disturbed resorption of the yolk sac until 21 day of life. When rape seed oil was used, resorption of the yolk sac was also not uniform, at 12 day of life complete resorption was observed only in $50 \%$ of at the chickens (Jamroz and Wertelecki, 1998a, b).

Serum $\alpha$-amylase activity was higher up to day 7 of life, after which this value declined. These results correspond with those obtained earlier by Wertelecki and Jamroz (1997), Jamroz and Wertelecki (1998a), and Jamroz et al. (1999). The intensive rise in the amylolytic activity and concomitant small differences in the activity of pancreatic lipase in 7 to 21 -day-old chickens support the observation that carbohydrates, not fat, are the main source of energy for chickens of this age.

The addition of fat to the feeds caused only small differences in the lipolytic activity of the pancreas. Initially, a weak, inhibitory effect of fat was observed on its development only on day 3 of life, whereas on day 21 its effect was stimulatory. This results from the gradual maturing of the digestive tract's ability to handle lipids and fully corroborates the observations of other authors that the availability of exogenous lipids increases with age, particularly after days 10-15 of life (Carew et al., 1972; Murakami, 1988, 1992; Senkoylu and Janssen, 1988; Chamblee et al., 1992; Dunnington and Siegel, 1995; Nitsan et al., 1995; Jamroz and Wertelecki 1998a,b; Jamroz et al., 1999). As results from the literature, if an excessive amount 
of fat is added to the diet, the level of lipase secretion to the serum may not rise above the physiological threshold (Nir et al., 1993).

The high level of serum enzymatic activity and concomitant low level in the tissue of the pancreas may point to the small degree of participation of the enzyme in hydrolyzing nutrients in the intestinal wall or lumen of the digestive tract.

The low activity of lipase in the pancreas of chickens may result from the fact that during the first 3 days of life, chickens utilize mainly the endogenous lipids in the yolk sac as an energy source. This fat is easily available, but must be hydrolyzed by endogenous lipase. This process also occurs through the direct absorption of lipids into the cells of yolk-sac membranes, where they are digested in the presence of lipase (Escribano et al., 1988; Gerhartz et al., 1997, 1999; Murray et al., 1999). A considerable part of active lipase is, therefore, in the membrane of the yolk sac, not in the pancreas, which may make explaining the lowering of serum lipase activity between days 1 and 3 of life difficult. The differentiated weight of the pancreas in the first days of life may be the result of increased development of secretory cells, whose number determines, among others, the level of enzyme secretion, in other words, directly affects digestive capabilities. The weight of this organ normalized on day 21 of life in chickens receiving $0-9 \%$ fat, as did enzyme activity.

The obtained results do not give fully satisfactory information about the effects of fat supplementation on the rate of resorption of the yolk sac and its components, but showed that a high level of fat in the diet is not conducive to the proper resorption of the sac and its contents.

\section{REFERENCES}

Carew L.B., Machemer R.H. Jr., Sharp R.W., Foss D.C., 1972. Fat absorption by the very young chick. Poultry Sci. 51, 738-742

Chamblee T.N., Brake J.D., Schultz C.D., Thaxton J.P., 1992. Yolk sac absorption and initiation of growth in broilers. Poultry Sci. 71, 1811-1816

Dunnington E.A., Siegel P.B., 1995. Enzyme activity and organ development in newly hatched chicks selected for high or low eight week body weight. Poultry Sci. 74, 761-770

Escribano E., Rahn B., Sell J.L., 1988. Development of lipase activity in yolk membrane and pancreas of young turkeys. Poultry Sci. 67, 1089-1097

Gerhartz B., Anerswald E.A., Mentle R., Fritz H., Machleidt W., Kolb H.J., Wittmann J., 1997. Proteolytic enzymes in yolk sac membrane of quail egg. Purfication and enzymatic charakterisation. Comp. Biochem. Physiol. Pt. B 111, 159-166

Gerhartz B., Kolb H.J., Wittmann J., 1999. Proteolytic activity in the yolk sac membrane of quail cggs. Comp. Biochem. Physiol. Pt. A 123, 1-8

Handbook of Biochemical Instructions, 1989. Wroclaw Agricultural University Press. ${ }^{\text {nd }}$ Edition. Wroclaw, pp. 128.129

Hemin Wang, Qiguang Huo, Shaobiao Li., 1994. Nutrient transfer in yolk sac of feeding chick. Acta Vet. Zoot. Sinica 2, 97-104 
Jamroz D., Wertelecki T., 1998a. Influence of fat addition to feed mixtures on the rate of yolk sac resorption in chickens, blood and pancreas enzyme activity. J. Anim. Feed Sci. 7, Suppl. 1, $271-276$

Jamroz D., Wertelecki T., 1998b. Effect of different amount of rape seed meal and enzyme supplementation on the yolk sac resorption and digestive tract development in chicks. Proceedings of $10^{\text {th }}$. European Poultry Conference, Jerusalem, Vol. II, pp. 811-814

Jamroz D., Wiliczkicwicz A., Wertelecki T., Orda J. Skorupińska J., 1999. Development of digestive iract, resorption of yolk sac, changes of pancreatic enzyme activity and fermentation rate in intestine in young chicks, ducks and geese. Proceedings of $12^{\text {th }}$ European Symposium on Poultry Nutrition. Veldhooven, pp. 168-170

Jin S.H., Corless A., Sell J.L., 1998. Digestive system development in post-hatch poultry. World Poultry Sci. J. 54, 335-345

Katanbar M.N., Dunnington E.A., Siegel P.B., 1988. Allomorphic relationships from hatching to 56 days of age in parental lines and F1 crosses of chickens selected 27 generations for high or low body weight. Growth, Develop. Aging 52, 11-22

Krogdahl A., Sell J.L., 1989. Influence of age on lipase, amylase and protease activites in pancreas tissue and intestinal contents of young turkeys. Poultry Sci. 68,1561-1568

Kuenzel W.J., Kuenzel N.T., 1977. Basal metabolic rate in growing chicks Gallus domesticus. Poultry Sci. 56, 619-625

Martin M.T., Fernandez E., Manteca X., Gonalons E., 1992. Absorbability of oleic and palmitic acid in young chicks. Effect of yolk sac ablation. Arch. Intern. Physiol. Biochem. Biophys. 100, 285288

Murakami H., Akiba Y., Horiguchi M., 1988. Energy and protein utilization in newly hatched chicks. Studies on early nutrition of poultry. Jpn. J. Zoot. Sci. 59, 890-895

Murakami H., Akiba Y., Horiguchi M., 1992. Growth and utilization of nutrients in newly-hatched chick with or without removal of residual yolk. Growth, Develop. Aging 56, 75-84

Murray A.M., Denis R., Speake B.K., 1999. Acyltransferase activities in the yolk sac membrane of the chick embryo. Lipids 34, 929-935

Nir I., Nitsan Z., Mahagna M., 1993. Comparative growth and development of the digestive organs and of some enzymes in broiler and egg type chicks after hatching. Brit. Poultry Sci. 34, 523-532

Nitsan Z., Turro-Vincent I., Liu G., Dunnington E.A., Sicgel P.B., 1995. Intubation of wcight-selected chicks with soybean oil or residual yolk: effect on early growth and development. Poultry Sci. $74,925-936$

Noy Y., Sklan D.,1995. Digestion and absorption in the young chick. Poultry Sci.74,366-373

Noy Y., Sklan D., 1997. Posthatch development in poultry. J. Appl. Poultry Res. 6, 344-354

Noy Y., Uni Z., Sklan D., 1996. Routes of yolk utilization in the newly-hatched chick. Brit. Poultry Sci. 37, 88-101

Nutrient Requirement of Poultry (in Polish), 1996. $3^{\text {rd }}$ revised Edition. The Kielanowski Institute of Animal Physiology and Nutrition (Editor), Jabłonna (Poland)

Pisarski R., Malec L., Borzemska B., Malec H., 1998. The influence of time of early feeding on body weight of chicks, yolk sac absorption and some blood serum elements (in Polish) Med. wet. 54, $607-611$

Pisarski R., Malec H., Malec L., 1998. The influence of early feeding on rate growth of chicks, yolk sac absorption and some blood serum elements (in Polish) Med. wet. 54, 409-412

Sell J., Angel C.R., Piquer F.J., Mallarino E.G., Albatshan H.A., 1991. Development patterns of selected characteristics of the gastrointestinal tract of young turkcys. Poultry Sci. 70, 1200-1205

Sklan D., Hurwitz S., 1980. Protein digestion and absorption in young chicks and turkeys. J. Nutr. $110,139-144$ 
Susbilla J.P., Frankler T.L., Parkinson G., Gow C.B., 1994. Weight of internal organs and carcass yicld of carly food restricted broilers. Brit. Poultry Sci. 35, 677-685

Senkoylu N., Janssen W.M.M.A., 1988. The influence of age, basic feed, fat type and inclusion levels upon apparent metabolizable energy values in chicken feeds. Proceedings of XVIII WPC. Nagoya (Japan), pp. 784-786

Turro-Vincent I., Dunnington E.A., Nitsan Z., Picard M., Siegel P.B., 1994a. Effect of yolk sac removal at hatch on growth and feeding behavior in lines of chickens differing in body weight. Growth, Develop. Aging 58, 105-112

Turro-Vincent I., Nitsan Z., Picard M., Dunnington E.A., Siegel P.B., 1994b. Removal of residual yolk at hatch influences food choice and feeding activity in lines of chickens selected for high or low juvenile body weight. Reprod. Nutr. Develop. 34, 449-460

Uni Z., Noy Y., Sklan D., 1995. Posthatch changes in morphology and function of the small intestine in heavy and light - strain chicks. Poultry Sci. 74, 1622-1629

Wertelecki T., Jamroz D., 1998a. Yolk sac resorption. digestibility tract development and alpha amylase activity changes in serum of chicken broilers. Proccedings of European Conference of WPSA, Jerusalem, Vol. II, pp. $811-814$

Wertelecki T., Jamroz D., 1998b. Yolk sac resorption rate, digestive tract development as well as changes of the alpha-amylase activity in chicken depending on their keeping system. Proccedings of the Conference "The Modern Problems in Breeding, Health and Production of Poultry", Ceske Budejovice (Czech Republic), p. 203

Wertelecki T., Jamroz D., 1999. The influence of high level of grains in mixtures on yolk sac resorption and enzyme activity changes in blood serum and pancreas in chickens (in Polish). Prz. hod. Zesz. Nauk. 45, Proccedings: Breeding Poultry. XII International Juvenile Conference of WPSA, Lublin-Kazimierz Dolny (Poland), pp. 335-345

\section{STRESZCZENIE}

Wpływ dodatku tluszczu zwierzęcego na tempo resorpcji woreczka żóltkowego, zmiany jego skladu chemicznego oraz aktywność enzymatyczną trzustki i surowicy krwi kurcząt

Badania przeprowadzono na 476 brojlerach kogutkach Shaver Starbro, podzielonych na 4 grupy i otrzymujących do woli mieszanki różniące sic̨ udziałem tłuszczu (smalcu): 0,3,6 lub 9\%. W 1,2,3,4,7,12 i 21 dniu życia kurczęta ważono, część ubijano i określano masę woreczka źółtkowego, a w jego treści oznaczano zawartość białka i tłuszczu surowego. We krwi i trzustce oznaczono aktywności amylazy i lipazy.

Kurczęta żywione natłuszczanymi mieszankami były cięższe w 21 dniu życia. Nic stwierdzono natomiast statystycznie istotnych różnic między grupami w ubytku masy woreczków żółtkowych. Wysoki udział tłuszczu w mieszance $(9 \%)$ zmniejszył tempo resorpcji woreczka żółtkowego, mimo to kurczçta rozwijały się prawidłowo. Wchłanianie białka $\mathrm{z}$ treści woreczków u kurcząt żywionych micszanką nie natłuszczaną postępowało równomiernie. Przy wiçkszej ilości smalcu w mieszance wystapiła tendencja zwalniania tempa ubytku lipidów z treści woreczka, a pewien wzrost natężenia tego procesu występował po 4 dniu życia. Dodatek smalcu do diet istotnie obniżył aktywność lipazy w trzustce w 3 dniu życia kurcząt i stopniowy jej wzrost pomiędzy 7 a 21 dniem zycia. Nathuszczanie mieszanek, w ilości od 6 do 9\%, obniżyło aktywność anılazy trzustkowej w 3 i 7 dniu życia piskląt. 